\title{
FREE TRADE AND CULTURAL INDUSTRY: FINDING A WAY TO SLEEP IN THE SAME BED
}

\author{
HEATHER GRAB ${ }^{*}$
}

This article discusses the consideration, often minimal, paid by international agreements to cultural products such as books, magazines, and films. The author advocates for the inter-connectedness of trade and culture and emphasizes the importance of striking a balance between the two concepts going forward. A discussion of differing conceptions of culture and an overview of how international instruments and international law treat culture and cultural industries is provided.

Adopting Canada as a focal point, the article discusses the country's unique role vis-à-vis its cultural protection strategies and how this has shaped relations between Canada and the United States. Ultimately, the author concludes that in the future, as globalization increases, considering culture alongside trade is crucial so as to protect and promote cultural diversity that compete with increasingly dominant economic forces.
Cet article porte sur la contrepartie, souvent minime, versée dans le cadre d'ententes internationales pour des produits culturels tels que des livres, des revues et des films. L'auteur préconise l'interconnexion du commerce et de la culture et souligne l'importance d'arriver à un équilibre entre les deux concepts dans l'avenir. On y discute des différentes conceptions de culture et on y donne un aperçu de la manière dont les instruments internationaux et le droit international traite la culture et les industries de la culture.

En adoptant le Canada en tant que point de mire, l'article porte sur le rôle unique du pays à l'égard de ses stratégies de protection culturelle et sur la manière que celles-ci ont façonné les relations entre le Canada et les États-Unis. En définitive, l'auteur conclut qu'à l'avenir, avec l'expansion de la mondialisation, il sera tout aussi important de tenir compte de la culture que du commerce pour protéger et promouvoir la diversité culturelle qui fait concurrence aux forces économiques de plus en plus dominantes.

\section{TABLE OF CONTENTS}

I. INTRODUCTION . . . . . . . . . . . . . . . . . . . . 422

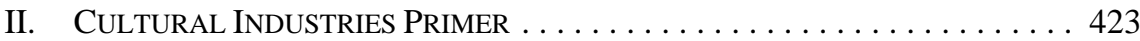

A. Common Methods of Protection . . . . . . . . . . . . . . 425

B. CANADA'S HistORICAL AND CURRENT POSITIONS

REGARDING CULTURAL INDUSTRIES . . . . . . . . . . 426

III. RELEVANT INTERNATIONAL LAW . . . . . . . . . . . . . . . 428

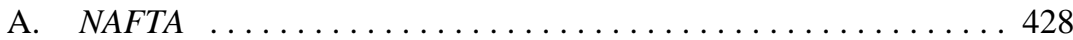

B. World TRAdE ORganization . . . . . . . . . . . . . . 429

C. CONVENTION ON THE PROTECTION AND

PROMOTION OF THE DIVERSITY OF

CULTURAL EXPRESSIONS . . . . . . . . . . . . . . . 431

IV. North AMERICAN TRAdE IsSUES $\ldots \ldots \ldots \ldots \ldots \ldots \ldots \ldots \ldots . \ldots \ldots 2$

A. THE PERIODICALS CASE AND

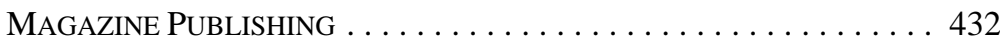

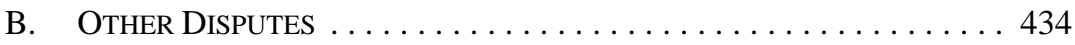

V. Challenges of Protecting ANd Promoting Cultural

INDUSTRIES ON AN INTERNATIONAL SCALE . . . . . . . . . 435

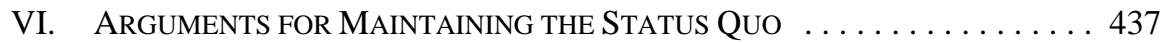

Student-at-Law, Macleod Dixon, Calgary. The author would especially like to thank Professor Linda

C. Reif at the University of Alberta for her guidance and wisdom throughout the writing of this article. 
VII. ARGUMENTS FOR CHANGE IN DEALING WITH

Trade AND Cultural Industries $\ldots \ldots \ldots \ldots \ldots \ldots \ldots \ldots \ldots$

VIII. FINDING A NEW WAY: PROMOTING CUlTURE AND

ENCOURAGING TRADE ....................... 440

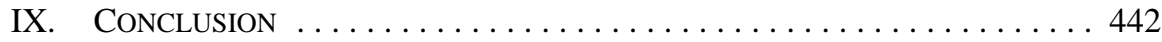

Regrettably, it is only in hindsight that the social and cultural after-effects of trade agreements are sought to be understood. ${ }^{1}$

\section{INTRODUCTION}

Culture and what constitutes and defines national identity have been, and will continue to be, prescient issues as the world increasingly moves in the direction of globalization and the concept of achieving what some may term a "global village." Pursuing the presumed ideal of free trade is often discussed as an inseparable appendage to globalization. In the process, however, certain non-economic interests, like culture, have been marginalized and at the same time internationalized. As a result, even while culture remains a largely contentious issue when it comes to international trade agreements, most agreements still barely reflect (or only consider in a somewhat haphazard and ill-conceived fashion) the fact that a number of nations throughout the world are concerned about the preservation of their respective cultures in the face of hegemonic encroachment. Nevertheless, trade and culture are "increasingly inextricable from one another."2 This presents a major challenge going forward in terms of how to strike a balance between the two in such a way that individual nations are able to enjoy the advantages that globalization and freer trade have to offer without feeling like their national identities are being eroded.

Canada is one nation that has dealt with constant pressure to protect, preserve, and promote its national cultural identity, specifically from the often overpowering influence of the United States. ${ }^{3}$ It cannot be overlooked that, according to an annual study conducted by Statistics Canada, in 2005 Canada’s imports of cultural goods were valued at over CDN\$4 billion. In contrast, exports in Canadian cultural goods totalled only $\$ 2.3$ billion. ${ }^{4}$ This is a trade deficit of approximately $\$ 1.7$ billion, an 8.4 percent increase over $2004 .^{5}$ As a result, Canada has undertaken a concerted effort to protect and promote its cultural industries including radio, television, film, and book and magazine publishing — from unwanted foreign hegemony.

Richard L. Matheny, III, “In the Wake of the Flood: 'Like Products' and Cultural Products after the World Trade Organization’s Decision in Canada Certain Measures Concerning Periodicals” (1998) 147 U. Pa. L. Rev. 245 at 250.

2 Ibid. at 270

3 While this article will primarily focus on Canada's position with respect to the U.S., other countries are dealing with similar issues within other geographical areas.

4 Statistics Canada, "Value of international trade in culture good, Canada, 1996 to 2005” (Summary Table) (June 2006), online: Statistics Canada <http://www.statcan.ca/english/freepub/87-007-XIE/ 2006001/sumtable.htm>.

5 Statistics Canada, “International trade in cultural goods” The Daily (12 June 2006), online: Statistics Canada <http://www.statcan.ca/Daily/English/060612/d060612b.htm>. 
This article will discuss how Canada has vigorously attempted, through a variety of avenues, to protect its cultural industries from a more dominant influence. Unfortunately, the methods currently being used have not proven to be overly successful on an international scale. A balance needs to be struck between encouraging free trade at the international level, and preserving and promoting Canada's cultural identity. At this point, the best way to accomplish this objective would be to create an international trade agreement dealing specifically and only with cultural industries.

After giving a primer on culture and cultural industries, including how they are commonly protected, how Canada has historically approached its cultural industries, and how Canada currently deals with the confluence of trade and culture, this article delves into the relevant international law that plays a role in trade and culture. A brief overview of some of the issues that have arisen in the recent past between Canada and the U.S. as an example of how international law has been applied to cultural products will then be provided. There are a number of arguments regarding whether change to the current trade in culture regime is really necessary and just as many arguments for why a new approach needs to be taken. While there are challenges to protecting and preserving cultural industries, these do not discount the necessity of an international agreement dealing with cultural industries and trade in culture. This article discusses what would be achieved by such an agreement along with other avenues a nation might take in attempting to maintain the integrity of its cultural identity.

\section{Cultural Industries Primer}

Culture can be defined myriad ways, which is actually part of the problem when it comes to trying to preserve culture within the framework of international trade. However, this article approaches "culture" as a nation's social and political discourse about itself that enables shared understandings, experiences, and values. ${ }^{6}$ Culture, therefore, as this definition would suggest, can be expressed in countless ways through a variety of mediums, for example, inter alia, a television show, a theatrical production, a magazine article, a literary book, or a song. And this is where cultural industries fit into the equation. Cultural industries, according to the United Nations Educational, Scientific and Cultural Organization (UNESCO), "are those industries that combine the creation, production and commercialisation of contents which are intangible and cultural in nature."7 This means that a television show, for example, may convey a nation's culture by way of how the characters relate to one another, the dramatic situations that arise, and even the words used in dialogue between characters. As a result, television can be considered a cultural industry because it is a medium by which intangible cultural markers are communicated. Typical cultural industries include the film and television industry, the publishing (books and magazines) industry, and the music industry.

6 Victor Rabinovitch, “The Social and Economic Rationales for Domestic Cultural Policies” in Dennis Browne, ed., The Culture/Trade Quandary: Canada's Policy Options (Ottawa: Centre for Trade Policy and Law, 1998) 25.

$7 \quad$ UNESCO, “Cultural Industries: 25 questions and answers to explore key concepts and ideas related to culture and trade in the context of development," online: UNESCO <http://portal0.unesco. org/culture/admin/ev.php?URL_ID=2461\&URL_DO=DO_TOPIC\&URL_SECTION=-512> at Answer 1 [UNESCO 25 Questions]. 
The international trade in cultural goods has increased dramatically in the last 20 years, largely as a function of increasing globalization. ${ }^{8}$ This has led some countries, like Canada, to re-evaluate how they think about and deal with culture as an explication of national identity and in the context of trade with other countries. "[C]ulture is not like any other merchandise because it goes beyond the commercial: cultural goods and services convey ideas, values and ways of life which reflect [the] plural identities of a country and the

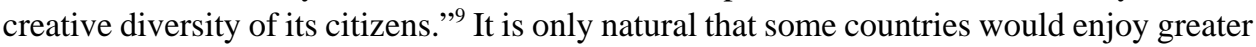
success at exporting their culture than might some other countries, and this is exactly the case when it comes to the U.S. and Canada. The U.S. has been extraordinarily successful at packaging and exporting what might be termed "the American experience" (especially to Canada but also to the rest of the world), while trade in Canadian culture has enjoyed limited success in markets beyond its border. ${ }^{10}$ Herein lies the reason why Canada has taken, and continues to take, a proactive approach to protecting and promoting its cultural industries. Canada is uniquely susceptible, as will be discussed later in this article, to advances by the U.S.

There is currently (and has been for some time) a major disconnect in how Canada and the U.S. view culture, and this has largely affected the way in which the two countries deal with each other when it comes to cultural industries. As one commentator notes: "In the United States, culture is the equivalent (basically) to entertainment, and is a good that is properly allocated by the market. In Canada (as in many European nations), culture is an expression of national identity and as such is to be promoted and protected as a public responsibility."11 As a result, more Canadian cultural goods are given greater national and political significance and are linked to the fostering of national identity than are American goods. Canada does not have the long and celebrated shared history of nation-making myths and heroes to the extent that the U.S. does. When this is considered alongside Canada's tireless propounding of itself as a multicultural country, we are left with the sense that Canada is constantly trying to piece together a cohesive, if somewhat nebulous, quilt of cultural identities. ${ }^{12}$ On the global stage, the European Union (EU) is currently dealing with this difficulty of bringing together multiple nations with highly variant cultural heritages into one framework "without compelling them to relinquish loyalties and attachments to ancestral

Ibid. at Answer 3.

Ibid. at Answer 16.

As a comparison, while Canada's exports of cultural goods totalled about CDN\$1.6 billion in 2002, the U.S. exported a total of more than CDN\$7.6 billion in the same time period. See UNESCO Institute for Statistics, International Flows of Selected Cultural Goods and Services, 1994-2003 (2005), online: UNESCO <http://www.uis.unesco.org/ev.php?ID=6383_201\&ID2=DO_TOPIC>."Canadian culture” is referred to in a broad sense, and this article refrains from engaging in a treatise of what exactly constitutes Canadian culture.

11 Kevin V. Mulcahy, "Cultural Imperialism and Cultural Sovereignty: U.S.-Canadian Cultural Relations" (2000) 30 Amer. Rev. Can. Studies 181 at 187-88.

12 See Canadian Charter of Rights and Freedoms, Part I of the Constitution Act, 1982, being Schedule B to the Canada Act 1982 (U.K.), 1982, c. 11, s. 27: "This Charter shall be interpreted in a manner consistent with the preservation and enhancement of the multicultural heritage of Canadians.” 
cultures."13 This is not an easy task, for the EU or for Canada, and requires a proactive approach to culture.

One of the questions that arises in trying to take a proactive approach is whether the protection and promotion of culture, and cultural industries in particular, is properly a realm for the government to be involved in, or whether society (that is, the individual) at large ought to be responsible in a more informal capacity at the market level. ${ }^{14}$ Also, if government is to play a role, to what extent should it be involved? Should only "struggling" cultural areas be helped and in what manner? Should the government take a more promotional line or be more protectionist, or both? These issues will be returned to at a later point, but for now, it is suggested that the government ought to play a role in the protection and promotion of Canadian cultural industries at a higher level and with an arm's-length stance from the actual content that is produced.

\section{A. Common Methods of Protection}

Canada, over the years, has used a variety of methods that fall on both sides of the protection/promotion coin to protect its cultural industries. "The current 'cultural policy toolbox' includes financial and program incentives, Canadian content requirements, and other regulatory support mechanisms, tax measures, foreign investment and ownership restrictions, and measures to protect intellectual property." 15 Some methods have been more or less successful in terms of implementation and effectiveness. Government subsidies are one way in which Canada has provided incentives to its cultural industries, in the form of postal subsidies for example, and sometimes by way of grants or tax incentives. Besides subsidizing individual artists, Canada has also developed certain cultural infrastructures that encourage and promote Canadian cultural works. ${ }^{16}$ These incentives are designed to promote Canadian culture. Canadian content requirements, a protection measure, ensure that Canadian television and music (among other things) are allowed the opportunity to be experienced by the public. For instance these content rules operate such that Canadian television channels must broadcast a certain amount of "Canadian" programming. ${ }^{17}$ Other measures that are intended to protect cultural industries include restrictions on foreign ownership and

13 Patricia M. Goff, “Invisible Borders: Economic Liberalization and National Identity” (2000) 44 Int’l Studies Q. 533 at 555 . The EU specifically turned its mind to the importance of cultural diversity within and among its member nations in art. 151 of its establishing treaty: European Commission (EC), Consolidated Versions of the Treaty on European Union and of the Treaty Establishing the European Community, [2002] O.J. C 321E at 113. See also the recent EC strategy document on culture: EC, Communication on a European agenda for culture in a globalizing world (24 May 2007), online: EC $<$ http://ec.europa.eu/culture/eac/communication/comm_en.html>. One fear is that the government, if it takes too much responsibility for culture, will inhabit a "Big Brother" role that may lead to increased censorship and, ultimately, a false culture that is out of touch with its citizens.

15 Liss Jeffrey, “The Impact of Technological Change on Canada's Affirmative Policy Model in the Cultural Industry and New Media Sectors” (1999) 25 Can.-U.S.L.J. 379 at 382.

16 For example, the National Film Board of Canada. See also John Herd Thompson, “Canada's Quest for Cultural Sovereignty: Protection, Promotion, and Popular Culture” in Stephen J. Randall \& Herman W. Konrad, eds., NAFTA in Transition (Calgary: University of Calgary Press, 1995) 393 at 396.

17 This is monitored by the Canadian Radio-television and Telecommunications Commission (CRTC) and is accomplished by way of a complicated system that awards points for various aspects of a program or song that make it "Canadian." 
investment, as well as restrictions on and heightened taxation of cultural imports. Unfortunately, as will be discussed in Part IV, some of these more protectionist measures have previously landed Canada in hot water with its neighbour to the south. As the Canadian government has tried various combinations and applications of these methods over the years, Canada's policy towards cultural industries has slowly shifted from a more internalized focus to a greater appreciation for the international scope of the issue.

\section{B. CANAdA's Historical AND CURRENT POSITIONS REGARDING CULTURAL INDUSTRIES}

Canada formally turned its mind to the issue of national identity and cultural protection and promotion around the turn of the 20th century with the establishment of a number of cultural instruments, including the National Gallery of Art in 1880 and the National Film Board in $1939 .{ }^{18}$ In 1949, the Royal Commission on National Development in the Arts, Letters and Sciences ${ }^{19}$ was created, and later produced a report often referred to as the Massey Report. ${ }^{20}$ The Order in Council for the Commission states " $[\mathrm{t}] \mathrm{hat}$ it is in the national interest to give encouragement to institutions which express national feeling, promote common understanding and add to the variety and richness of Canadian life, rural as well as urban." ${ }^{21}$ Clearly, the issue of culture was of great interest and importance to Canada, and the Massey Report spent a great deal of time discussing Canada's cultural industries and the influence that the U.S. in particular had thus far exerted over Canadian mass media and education.

In 1968, in response to the phenomenal growth of television broadcasting, Canada passed the Broadcasting Act. ${ }^{22}$ The Act states that "the Canadian broadcasting system should ... serve to safeguard, enrich and strengthen the cultural, political, social and economic fabric of Canada." ${ }^{23}$ Here, a more proactive stance focused on encouraging and protecting Canadian broadcasting was undertaken by the federal government. At the same time, the Act created what is now known as the Canadian Radio-television and Telecommunications Commission (CRTC), a federal agency that regulates the broadcasting system and telecommunications in Canada. ${ }^{24}$ It is also important to note that the Canadian Broadcasting Corporation (CBC), a Crown corporation, "marks the most visible difference between the cultural industries of Canada and the United States: Canada has a publicly owned and publicly financed radio and television broadcasting system, and the United States does not."25

18 See "Overview of the National Cultural Institutions,” online: Government of Canada <http://geo. international.gc.ca/canada-europa/master/culture/national_cultural_institutions-en.asp>. See "Royal Commission on National Development in the Arts, Letters and Sciences 1949-1951," online: Library and Archives Canada <http://www.collectionscanada.ca/2/5/index-e.html>.

20 Canada, Royal Commission on National Development in the Arts, Letters and Sciences 1949-1951 (Ottawa: King's Printer, 1951) (Chair: Vincent Massey), online: Library and Archives Canada <http:// www.collectionscanada.ca/2/5/h5-400-e.html> [Massey Report].

Ibid. at xi.

S.C. 1991 , c. 11 .

Ibid., s. 3(1)(d).

For more information, see online: CRTC <http://www.crtc.gc.ca>.

Thompson, supra note 16 at 397. The CBC was created in 1936 to regulate, produce, and broadcast radio and television programming. 
Moving forward, relations between the U.S. and Canada with respect to cultural industries were formally solidified to some extent in the Free Trade Agreement Between the Government of Canada and the Government of the United States of America, ${ }^{26}$ after lengthy negotiations. The cultural exemption contained therein became part of the subsequent North American Free Trade Agreement, ${ }^{27}$ and will be discussed in more detail in Part III.

While the inclusion of the cultural exemption in the CUSFTA, and later in the NAFTA, was important to having Canada's cultural considerations acknowledged on a more international scale, Canada was also undertaking other methods of protecting and promoting its cultural industries with an eye beyond its border. The Investment Canada Act plays a protectionary role by reserving the ability to subject foreign investment in Canada to additional scrutiny if the investment regards an "activity that ... is related to Canada's cultural heritage or national identity." 28 In addition, relating specifically to publishing, the Foreign Publishers Advertising Services $A c t^{29}$ places restrictions on the amount of advertising directed at the Canadian market that may be used by foreign publishers. ${ }^{30}$ The pool of Canadian advertisers is finite and limited, and the intent of the legislation is to ensure that most of the Canadian advertising revenue available goes to Canadian publishers (as opposed to being just another drop in the bucket for American publishers who have the benefit of huge economies of scale).

In addition, Canada has put in place a network of support for Canadian culture and cultural industries. The Cultural Industries Sectoral Advisory Group on International Trade (SAGIT) produced two reports ${ }^{31}$ that were instrumental in Canada pursuing the idea of an international instrument on cultural diversity, eventually resulting in the UNESCO Convention on the Protection and Promotion of the Diversity of Cultural Expressions. ${ }^{32}$ Then there is Trade Team Canada - Cultural Goods and Services that was originally established by the Department of Canadian Heritage. ${ }^{33}$ This Trade Team Canada sector facilitates a "two-way flow of information and advice between the Government of Canada ... and the arts and cultural stakeholders in the private and public sector, on cultural export development issues." ${ }^{34}$ In this way, Canada looked toward the preservation and promotion of its cultural

2 January 1988, Can. T.S. 1989 No. 3, 27 I.L.M. 293 (entered into force 1 January 1989) [CUSFTA]. North American Free Trade Agreement Between the Government of Canada, the Government of Mexico and the Government of the United States, 17 December 1992, Can. T.S. 1994 No. 2, 32 I.L.M. 289 (entered into force 1 January 1994) [NAFTA].

R.S.C. 1985 (1st Supp.), c. 28, s. 15(a).

S.C. 1999 , c. 23.

This statute will be discussed further in Part IV, below, where it will be seen that the Act, as it currently stands, is drastically altered from its original and intended state where advertising restrictions are concerned.

SAGIT, New Strategies for Culture and Trade: Canadian Culture in a Global World (1999), online: Foreign Affairs and International Trade Canada (FAITC) <http://www.maeci-dfait.gc.ca/tnanac/canculture-en.asp>; SAGIT, An International Agreement on Cultural Diversity: A Model for Discussion (2002), online: FAITC < http://www.maeci-dfait.gc.ca/tna-nac/documents/sagit_eg.pdf> [New Strategies].

20 October 2005 (entered into force 18 March 2007), online: UNESCO <http://unesdoc.unesco.org/ images/0014/001429/142919e.pdf> [Convention]. This Convention came into force only recently and will be discussed further in the next section.

Trade Team Canada - Cultural Goods and Services, online: Canadian Heritage <http://www. canadianheritage.gc.ca/TradeTeamCanadaCulture/>.

Ibid. at "Mandate." 
industries with a greater global outlook and understanding; it was no longer enough for Canada to focus its attention wholly within its borders without considering the effects of doing so in a globalizing world.

\title{
III. RELEVANT INTERNATIONAL LAW
}

The protection and promotion of cultural industry are increasingly being recognized in international agreements and the like, especially as some countries have begun to recognize that while free trade brings many benefits, it does not always equal fair trade. For Canada and its relations with the U.S., the NAFTA and the World Trade Organization's General Agreement on Tariffs and Trade ${ }^{35}$ have generally played the largest role with respect to the tug-of-war over cultural industries. However, these are not the only international instruments with a role to play in the issue — the recent UNESCO Convention, among others, also bears on the situation.

\section{A. NAFTA}

In Canada, the culture issue reached a particularly contentious high during the negotiations of the CUSFTA between Canada and the U.S., resulting in Canada including a cultural industries exemption in the agreement. ${ }^{36}$ This exemption, at Canada's insistence, was carried over and included in the subsequent NAFTA. ${ }^{37}$ The cultural industries exemption states:

\begin{abstract}
Notwithstanding any other provision of this Agreement, as between Canada and the United States, any measure adopted or maintained with respect to cultural industries, except as specifically provided in Article 302 (Market Access - Tariff Elimination), and any measure of equivalent commercial effect taken in response, shall be governed by this Agreement exclusively in accordance with the provisions of the Canada - United States Free Trade Agreement. The rights and obligations between Canada and any other Party with respect to such measures shall be identical to those applying between Canada and the United States. ${ }^{38}$
\end{abstract}

At first glance, it might seem that Canada garnered for itself an exemption of broad application, which would have been the case had the exemption not also included a

3530 October 1947, 58 U.N.T.S. 187, Can. T.S. 1947 No. 27 (entered into force 1 January 1948), including Annex 1A, Agreement Establishing the World Trade Organization, 15 April 1994, 1867 U.N.T.S. 154, 33 I.L.M. 1144, (entered into force 1 January 1995) [WTO Agreement] [collectively referred to as the GATT].

36 James W. Dean \& Vivek H. Dehejia, “Would a Borderless North America Kill Canadian Culture?” (2006) 36 Amer. Rev. Can. Studies 313.

37 It is unclear why Mexico did not reserve a cultural exemption for itself; however, it is not as susceptible to U.S. cultural encroachment due in large part to the barrier of language.

$38 \quad$ NAFTA, supra note 27, art. 2106, annex 2106. Cultural industries are defined at art. 2107 as:

(a) the publication, distribution, or sale of books, magazines, periodicals or newspapers in print or machine readable form but not including the sole activity of printing or typesetting any of the foregoing;

(b) the production, distribution, sale or exhibition of film or video recordings;

(c) the production, distribution, sale or exhibition of audio or video music recordings;

(d) the publication, distribution or sale of music in print or machine readable form; or

(e) radiocommunications in which the transmissions are intended for direct reception by the general public, and all radio, television and cable broadcasting undertakings and all satellite programming and broadcast network services.

See also CUSFTA, supra note 26, art. 2005(2). 
retaliation provision. This retaliatory mechanism allows the U.S. to take "any measure of equivalent commercial effect" in response to any Canadian measure protecting its cultural industries. As a result, it has been noted that this mechanism effectively "nullifie[s] the cultural exemption by allowing a kind of economic blackmail with threats of adverse actions against other sectors of the Canadian economy"39 — and the exemption is rendered basically useless.

Fortunately, Canada learned its lesson well (especially after the U.S. had threatened retaliatory action in disagreements over how Canada was protecting its cultural industries) and has since signed free trade agreements, as well as foreign investment protection agreements, with other countries around the world that include a cultural exemption without an accompanying retaliation provision. ${ }^{40}$

\section{B. WORLD TRADE ORgANIZATION}

There are a number of agreements annexed to the WTO Agreement, including the GATT, the General Agreement on Trade in Services, ${ }^{41}$ and Agreement on Trade-Related Aspects of Intellectual Property. ${ }^{42}$ While the GATT is the primary agreement that seems to be referred to regarding the issue of cultural industries, especially where Canada is considered, the application of the GATS and the TRIPS Agreement must not be overlooked.

The GATT, unlike the NAFTA, does not contemplate the protection or promotion of cultural industries beyond a small exception for films. ${ }^{43}$ This does not, nevertheless, mean that culture is without a place in the trade regime. In fact, the GATT and, more generally, the WTO, are supposed to be about liberalizing trade rather than ensuring total laissez-faire trade with no concern for non-trade-related matters. ${ }^{44}$ It is for this reason that the WTO regime would seem to be the best venue for an international cultural industries trade agreement so that the influence on culture by the application of the trade agreements can be effectively tempered. Where Canada is concerned, the national treatment principle of the GATT has played the largest role in relation to cultural industries. This principle is one of internal nondiscrimination such that if a state grants a particular right or benefit relating to goods to its citizens, the state must also accord that same right or benefit to citizens of other nations that are signatories to the GATT, who are present in the state.

The national treatment principle includes the concepts of "like products" and "directly competitive products" in helping to adjudicate whether the principle has been violated.

$39 \quad$ Mulcahy, supra note 11 at 189.

$40 \quad$ "International trade and investment rules governing the cultural sector," online: Canadian Heritage <http://www.canadianheritage.gc.ca/progs/ac-ca/progs/rc-tr/progs/dpci-tipd/pubs/cdpc-ctpl/8_e.cfm>. For an example of such a cultural industries exemption, see Free Trade Agreement Between the Government of Canada and the Government of the Republic of Chile, 5 December 1996, 36 I.L.M. 1067 (entered into force 2 June 1997), art. O-06, annex O-06.

$41 \quad$ Annex 1B, WTO Agreement, supra note 35 [GATS]

42 Annex 1C, WTO Agreement, ibid. [TRIPS Agreement].

43 See supra note 35, art. IV.

44 See generally Peter Van den Bossche, The Law and Policy of the World Trade Organization: Text, Cases and Materials (Cambridge: Cambridge University Press, 2005); Autar Krishen Koul, Guide to the WTO and GATT: Economics, Law and Politics (The Hague: Kluwer Law International, 2005). 
Article III(2) of the GATT, dealing with taxation measures, contains the "like products" clause and states:

The products of the territory of any contracting party imported into the territory of any other contracting party shall not be subject, directly or indirectly, to internal taxes or other internal charges of any kind in excess of those applied, directly or indirectly, to like domestic products. Moreover, no contracting party shall otherwise apply internal taxes or other internal charges to imported or domestic products in a manner contrary to the principles set forth in paragraph $1 .^{45}$

Annex I later amended the provision to infuse the "directly competitive" concept into the analysis, such that art. III(2) now has an additional sentence:

A tax conforming to the requirements of the first sentence of paragraph 2 would be considered to be inconsistent with the provisions of the second sentence only in cases where competition was involved between, on the one hand, the taxed product and, on the other hand, a directly competitive or substitutable product which was not similarly taxed. ${ }^{46}$

As will be seen in Part IV, this analysis had a devastating effect on Canada's attempts at protecting and promoting its publishing industry due in large part to the fact that even if one can successfully surmount the "like products" analysis, there is still the "directly competitive" analysis to contend with. In comparison to the concept of "like products," this analysis is less contextual, thereby making a meaningful discussion of what it means to be a cultural product far more difficult. ${ }^{47}$

Another provision of the GATT that is relevant to the discussion of cultural industries is art. XI(1). The objective of this provision is the general elimination of quantitative restrictions, and it states that " $[\mathrm{n}]$ o prohibitions or restrictions other than duties, taxes or other charges ... shall be instituted or maintained by any contracting party on the importation of any product of the territory of any other contracting party or on the exportation or sale for export of any product destined for the territory of any other contracting party." ${ }^{48}$ As a result, a nation's attempts to domestically protect its cultural industries may contravene art. XI, along with violating the national treatment principle.

Part of the issue with respect to the application of the GATT is that, where cultural industries are concerned, it often overlaps with the GATS. For example, audiovisual works may fall under the jurisdiction of the GATS (since they have not as yet been expressly included or excluded), however they have characteristics of both goods and services, with the result that the GATT may also be triggered. This has resulted in a degree of uncertainty

$45 \quad$ Supra note 35, art. III(2) [emphasis added]. Additionally, see art. III(4) which states: “The products of the territory of any contracting party imported into the territory of any other contracting party shall be accorded treatment no less favourable than that accorded to like products of national origin in respect of all laws, regulations and requirements affecting their internal sale, offering for sale, purchase, transportation distribution or use."

$46 \quad$ Ibid., annex I, art. III, para. 1 [emphasis added].

47 As will be seen later, art. XX of the GATT, which contains the general exceptions, may be used in an attempt to justify a measure that would otherwise violate the national treatment principle contained in art. III. GATT, supra note 35, art. XI(1). 
in terms of the application of these agreements. A number of countries, including Canada, argued for a cultural exemption during negotiations of the GATS, but to no avail. ${ }^{49}$ The GATS's Annex on Telecommunications even states that the Annex does not apply to "measures affecting the cable or broadcast distribution of radio or television programming." 50 Therefore, the elephant in the bedroom remains, and the GATS is left with no explicit exemption for, or even opinion on, culture generally and cultural industries specifically.

Finally, there is the TRIPS Agreement, which seems to have made the issue of cultural industries only more prescient. As one commentator noted, "[t]he interest of the foreign copyright holder in being guaranteed free market access worldwide conflicts with the interest of a nation such as Canada that seeks to restrict market access in favour of domestic cultural expressions." 51 Again, culture and trade’s effects on the Agreement are not contemplated, with the result that although cultural industries always seem to be part of the negotiation process, they remain absent from the final document.

\section{Convention on the Protection And Promotion of the DIVERSITY OF CULTURAL EXPRESSIONS}

On 18 March 2007, the legally binding international instrument, UNESCO's Convention on the Protection and Promotion of the Diversity of Cultural Expressions, came into force. ${ }^{52}$ However, it had its roots in the workings of the International Network of Cultural Policy (INCP). Canada was instrumental in establishing the INCP in 1998 in an effort "explore and exchange views on new and emerging cultural policy issues and to develop strategies to promote cultural diversity in an informal venue." 53 One of the major objectives of the INCP was to create an international instrument on cultural diversity that would help in the effort to protect and promote culture as the world globalizes, and also to "strengthen cultrual policies so that governments, together with civil society, can create an international environment that values diversity, creativity, accessibility and freedom." ${ }^{54}$ It should be noted that the U.S. is not a member.

Among its objectives, the Convention seeks:

(g) to give recognition to the distinctive nature of cultural activities, goods and services as vehicles of identity, values and meaning;

(h) to reaffirm the sovereign rights of States to maintain, adopt and implement policies and measures that they deem appropriate for the protection and promotion of the diversity of cultural expressions on their territory. ${ }^{55}$

See Myra J. Tawfik, “Competing Cultures: Canada and the World Trade Organization - The Lessons from Sports Illustrated” (1998) 36 Can. Y.B. Int’l L. 279.

Supra note 35, Annex on Telecommunications, art. 2(b).

Tawfik, supra note 49 at 288.

Supra note 32.

INCP, "What is the International Network on Cultural Policy," online: INCP <http://www.incpripc.org/about/index_e.shtml> [emphasis in original].

Ibid.

Supra note 32, art. 1(g), (h). 
Accordingly, the Convention is meant to aid in the process of bridging the gap between trade and culture, along with ensuring that culture is acknowledged and encouraged as a relevant and important part of the discourse on international trade. The concept of balance grounds the operation of the Convention as it seeks to "promote the production of, and access to, domestic cultural content," 56 while at the same time encouraging cultural content from other nations. Canada was the first nation to ratify the instrument, doing so on 28 November 2005; however, the U.S. is still conspicuously absent from the list of parties. ${ }^{57}$ Nevertheless, 59 nations and the EU are currently party to the Convention. ${ }^{58}$ It is clear that the issue of cultural diversity within the context of the trade sphere is of some concern, and the Convention represents a major step forward in recognizing the interaction of cultural and economic concerns. $^{59}$

Based on this brief overview of the relevant international instruments and organizations, one can see that culture and cultural industries are still relegated to, at most, a minor role when it comes to economic and trade interests on an international scale, specifically in terms of the NAFTA and the GATT. The U.S. and Canada have endured some major trade disagreements with one another and these instruments have been relied upon to bridge the gap, although not always in expected ways.

\section{NORTH AMERICAN TrADE ISSUES}

Canada and the U.S. have had a somewhat tumultuous relationship when it comes to cultural industries and Canada's insistence on protecting them in the face of American dominance. The Canada - Certain Measures Concerning Periodicals ${ }^{60}$ case from the mid1990s is perhaps the best example of how two international agreements, the NAFTA and the GATT, played out in the context of cultural industries. Since that case, there have been a few flare-ups of discontent with regard to cultural protection that merit attention.

\section{A. The Periodicals Case and Magazine Publishing}

The Periodicals case was triggered by Time Warner's intention to sell a Canadian version of Sports Illustrated in Canada, containing Canadian advertising and American content. ${ }^{61}$ When the U.S. filed its complaint with the WTO, it was responding to Canada's attempt to close a loophole in a piece of legislation that effectively allowed a split-run magazine to be

INCP, "Frequently Asked Questions - The Relationship Between a Convention on Cultural Diversity and International Trade Rules,” online: INCP <http://www.incp-ripc.org/iicd/faq_e.shtml> .

See the UNESCO website relating to the Convention, supra note 32, online: <http://portal.unesco. org/culture/en/ev.php-URL_ID=11281\&URL_DO=DO_TOPIC\&URL_SECTION=201.html >.

Ibid.

Ten Keys to the Convention on the Protection and Promotion of the Diversity of Cultural Expressions (2005), online: UNESCO <http://unesdoc.unesco.org/images/0014/001495/149502E.pdf>.

(1997), WTO Doc. WT/DS31/R (Panel Report), online: SICE <http://www.sice.oas.org/DISPUTE/ wto/period.asp> [Periodicals case (Panel)]; (1997), WTO Doc. WT/DS31/AB/R (Appellate Body Report), online: SICE <http://www.sice.oas.org/DISPUTE/wto/perpr.asp> [Periodicals case (Appellate Body)].

See Matheny, supra note 1. 
sold in Canada. ${ }^{62}$ Split-run magazines contain essentially the same editorial content, but have advertising that is geared toward the specific geographic market within which the magazine is sold: "The argument is that split-runs compete at an unfair disadvantage with Canadian magazines for advertising, having already paid production costs with the U.S. advertising." The advertising pool in Canada available for magazines is finite, therefore taking a percentage of the advertising revenue away has a noticeable effect on Canadian publications.

The offending piece of Canadian legislation "imposed an eighty percent [excise] tax on the value of all advertisements contained in a split-run edition." 64 The U.S. responded by utilizing the WTO's dispute settlement procedure. It is worth mentioning that when the NAFTA and the cultural industries exemption contained therein came into force, the WTO did not yet exist. Had the WTO not come into existence when it did, the U.S. would have been relegated to responding to the excise tax using the NAFTA's dispute resolution process - perhaps with little success given the cultural industries exemption. However, when the complaint was raised in 1996, the WTO and the NAFTA were both in force and the U.S. enjoyed a choice of forums.

The U.S.'s complaint against Canada eventually made its way to a WTO panel hearing and then to the Appellate Body to review the matter. Three arguments were put forth by the U.S.:

1) The restriction on the import of split-run magazines contravened art. XI of the GATT which seeks to eliminate general quantitative restrictions on the import of many goods;

2) The 80 percent excise tax on advertisements in split-run editions violated Canada's obligations under the "national treatment" principle contained in art. III of the GATT;

3) “The application by Canada Post of lower postal rates to domestically-produced periodicals" was inconsistent with Canada's obligations under the "national treatment" principle of the GATT. ${ }^{65}$

Canada, in response, argued that the first argument submitted by the U.S. was justifiable under art. XX(d) of the GATT $^{66}$ as a necessary measure to comply with the Income Tax Act, ${ }^{67}$ with the objective of helping "the Canadian periodical industry raise advertising revenues."68 Regarding the second argument put forth by the U.S., Canada responded that the national treatment principle did not apply to the excise tax or, alternatively, if it did apply, then the

Act to Amend the Excise Tax Act and the Income Tax Act, S.C. 1995, c. 46 was the offending legislation used by Canada to plug the loophole in Tariff Code 9958. Note that much of the commentary refers to this Act as Bill C-103.

Mulcahy, supra note 11 at 192.

Matheny, supra note 1 at 259.

Periodicals case (Panel), supra note 60 at para. 3.1. See also Matheny, ibid. at 260.

Periodicals case (Panel), ibid. at para. 3.2. This particular provision is a general exception to the GATT and states that a measure may be excepted if it is "necessary to secure compliance with laws or regulations which are not inconsistent with the provisions of this Agreement": see GATT, supra note 35, art. $\mathrm{xx}(\mathrm{d})$.

R.S.C. 1985 (5th Supp.), c. 1.

Periodicals case (Panel), supra note 60 at para. 3.5. 
excise tax was consistent with the principle. Finally, in response to the third argument by the U.S., Canada stated that the national treatment principle did not apply and that the lower postal rates qualified as an allowable subsidy under the GATT. ${ }^{69}$

The Appellate Body, having little precedent to consider in the area of cultural goods, agreed with the U.S. on all three arguments, although Canada did prevail on the third argument at the Panel level. The Appellate Body found that split-run magazines and domestically produced magazines were "like products" and "directly competitive" with one another, in essence, finding "that magazines were goods like any other commodity,"”70 without considering the contextual nature of goods infused with culturally significant elements. Canada had argued that “[c]ontent plays a role in the case of cultural products that is analogous to physical properties in the case of ordinary items of trade. Content is what the reader is looking for - the message and not the medium." ${ }^{, 71}$ Nevertheless, the WTO Appellate Body refrained from embracing the concept that a product might be differentiated from another product based on content rather than just physical and usage characteristics. Canada was thus left scrambling to change its legislation respecting the excise tax and postal rates.

When Canada moved to amend the 80 percent excise tax with Bill C-55, which severely limited the amount of Canadian advertising to which split-runs would have access, the U.S. responded vehemently and true to form: "[T]he Americans threatened ... to apply punitive tariffs against Canadian exports of steel, wood products, plastics, and textiles"72 — certainly more than what would be considered of equivalent commercial effect under the retaliation aspect of the NAFTA cultural industries exemption. Nevertheless, in an effort to avoid an all out trade war, Canada (also in true form) backed off and compromised with an amended version of Bill C-55 that requires split-run magazines to have no more than 18 percent Canadian advertising, or if they want more access to the Canadian advertising market, the editorial content must be at least 50 percent Canadian. ${ }^{73}$

\section{B. OTHER DISPUTES}

In the early 1990s, the U.S.-based Country Music Television (CMT) moved into the Canadian market and began broadcasting, but was subsequently blocked by the CRTC, who did this in favour of Canada's own country music station, New Country Network. While neither the Canadian government nor the American government took an official stance on the situation, the U.S. Trade Representative threatened retaliation against other Canadian cultural industries. At the end of the day, CMT was allowed to enter the Canadian market

$69 \quad$ Ibid. at para. 3.2.

$70 \quad$ Jeffrey, supra note 15 at 380.

$71 \quad$ Periodicals case (Panel), supra note 60 at para. 3.68. Canada also argued that the GATS applied, but the WTO Appellate Body held that the issue pertained to trade in goods and so properly fell under the jurisdiction of the GATT: see Periodicals case (Appellate Body), supra note 60 at VIII.

72 Gilbert Gagné, "North American Integration and Canadian Culture” in George Hoberg, ed., Capacity for Choice: Canada in a New North America (Toronto: University of Toronto Press, 2002) 159 at 168.

$73 \quad$ See ibid. at 173; David Taras, "Swimming Against the Current: American Mass Entertainment and Canadian Identity” in David M. Thomas, ed., Canada and the United States: Differences that Count, 2d ed. (Peterborough: Broadview Press, 2000) 192 at 202. 
after it merged with New Country Network, and the television station is now known as CMT within Canada. $^{74}$

The foreign ownership of cultural industries continued to be a concern and was raised again when the U.S.-based Borders, Inc. (a bookseller) attempted to open a store in Toronto. This move was rejected by the Canadian government under the auspices of the Investment Canada Act. ${ }^{75}$ Additionally, it has been noted that "the main issue was that Canadian booksellers could not match the economies of scale of such a large retailer, and would be edged out of the market." ${ }^{\text {"76 }}$ The fear was that a large American retailer could offer deeper and better discounts as compared to similar Canadian competitors and especially small Canadian bookstores, with the eventual result that less Canadian material might be made available to Canadian consumers at greater cost.

As these examples show, the protection and promotion of cultural industries is, and will continue to be, a recurring and growing issue not only between Canada and the U.S., but also among other nations of the world. The Periodicals case reveals the shortcomings of the GATT in dealing with cultural considerations and the sheer impotence of the NAFTA exemption in application (and in the face of the WTO dispute settlement process) ${ }^{77}$ Clearly, something more needs to be done to rectify the current disarray of how cultural industries are dealt with in the context of trade, but this road will not be without its hurdles.

\section{Challenges of Protecting AND Promoting Cultural Industries on AN INTERNATIONAL SCALE}

Given the fact that culture is by nature a very fluid and subjective concept, it is difficult to define and apply it effectively to trade considerations. For example, "[i]n North America, while Americans tend to think of culture in terms of fine arts, literature, opera, ballet and classical music (high culture); for Canadians it also encompasses books, magazines, newspapers, movies, video and music recordings, radio, and television." ${ }^{\text {"7 }}$ This creates a natural dissonance between what the U.S. and Canada think ought to be protected. While not all of the issues are likely to be overcome, one method of nailing down the concept of culture may be to discuss it in terms of cultural industries, a much more definable area. This means that culture, in a general and theoretical sense, can ideally retain some of its indefinable character while at the same time the method of disseminating culture can be protected and promoted in a more quantifiable manner. Of course, this raises a highly relevant question: what constitutes a cultural industry that is worthy or deserving of protection? I do not pretend

See Thompson, supra note 16 at 409. For more information see also Joseph Devlin, "Canada and International Trade in Culture: Beyond National Interests” (2004) 14 Minn. J. Global Trade 177 at 180. CMT ended up with a 33 percent stake in New Country Network (the maximum allowed under Canadian law).

75 Supra note 28.

${ }^{76}$ Devlin, supra note 74 at 181.

77 The fact that the WTO dispute settlement regime is more legalistic than the NAFTA c. 20 inter-state dispute settlement process might help explain this situation.

78 Gilbert Gagné, "Cultural sovereignty, identity, and North American integration: on the relevance of the U.S.-Canada-Quebec border” (2003), online: Access my Library <http://www.accessmylibrary.com/ coms2/summary_0286-3772167_itm>. 
to answer this question, but I would suggest that it needs to be considered on an ongoing basis.

One major hurdle is attaining acknowledgement of the reality that the protection of cultural industries from hegemonic cultures is necessary in the first place. It is difficult to get one nation to agree with the idea that another nation's cultural product should be protected when that first nation does not view the cultural product as culture. "Because they do not speak the same language with regard to culture, Americans have never taken Canadian complaints of U.S. cultural domination seriously."79 As a result, it becomes necessary to promote a wider acceptance and appreciation for the diverse ways in which culture can be promulgated. Additionally, a leader in the trade of culture has little to fear from those whose cultures may be more susceptible to a more prolific or "popular" culture and, since the leader may only see the economic aspects of culture, the leader is less likely to understand or accept the plight of the threatened culture. ${ }^{80}$

A corollary consideration involves measuring the effectiveness of protections in place, and accurately identifying when protections are no longer necessary. In short, it must be proven that the methods in place "do indeed contribute to the protection and promotion of local culture and to the safeguarding of cultural diversity," ${ }^{11}$ otherwise, what is the point? As one pair of commentators note, "there may exist an optimal extent to which countries ... should lay themselves bare to unprotected relations with their neighbors." ${ }^{22}$ A balance needs to be struck between protecting culture and cultural industries, while at the same ensuring that they compete on a more level playing field with the cultural industries of more dominant cultures.

Another challenge is the fact that there exists an element of corporate social responsibility that must fit into the equation in pursuit of a "fair" trade scenario with respect to cultural industries. While governments and international organizations can do a lot in enabling the trade in culture to occur on a more equalized basis, they can only go so far. Without delving into the theoretical arguments regarding the viability of the concept of corporate social responsibility, I would suggest that companies trading in cultural goods and services need to consider the implications of doing so in other countries and take a moment to consider how another country views culture and its own cultural industries.

Finally, there remains the issue that cultural products involve the confluence of a social utility with a public good. This means that a more contextual discussion needs to occur where a cultural good or service is concerned, since it is impossible to consider such a good or service independently from its content and/or cultural implications. Unfortunately, this is extraordinarily difficult where trade and economics are concerned as both rely on highly quantitative, rather than qualitative, analyses. It is time to make sure that the social and cultural implications of an economic transaction be considered beyond the actual economic transaction itself.

\footnotetext{
79 Thompson, supra note 16 at 398.
}

$80 \quad$ See Mulcahy, supra note 11 at 182.

81 Tomer Broude, “Taking ‘Trade and Culture’ Seriously: Geographical Indications and Cultural Protection in WTO Law” (2005) 26 U. Pa. J. Int'l Econ. L. 623 at 691. 
These challenges for protecting and promoting cultural industries are unlikely to go away or be completely resolved and, as a result, there remain arguments on both sides of the issue regarding whether change in the international arena ought to occur.

\section{Arguments for Maintaining the Status Quo}

In the Canadian context, there are four main arguments for merely maintaining what is currently in place for dealing with cultural industries. These arguments can easily be extrapolated to apply to other countries interested in protecting their cultural industries from encroachment.

First, there is the argument that Canada's cultural exemptions unfairly restrict free trade. This point has been raised by the U.S. repeatedly over the years: "What Canadians see as policies designed to pursue legitimate cultural and national goals, Americans see as barriers to free trade." 83 As discussed previously, this argument is representative of the disconnect between how the U.S. and Canada view their respective actions when it comes to cultural industries. Nevertheless, free trade does not equal trade that is completely unencumbered; in order for free trade to truly be achieved, it must be fair as well and this means there is some responsibility inherent in being able to trade freely. As a result, while Canada's cultural exemptions may create some restrictions on trade, they are intended to do so for the very real purpose of evening the economic playing field in Canada when it comes to the availability and consumption of Canadian cultural goods and services.

The second major argument suggests that cultural protection has been ineffective (and so further protections are not necessary), due in large part to the difficulty in efficiently or accurately measuring the effects of cultural protections that are currently in place. While this is a valid concern moving forward, it does not negate the reality that many nations, especially Canada, feel that cultural protections are necessary to maintain the integrity of their cultural industries. The fact that current measures may be ineffective or difficult to measure means that something needs to change about how cultural protections are applied: it is not an argument for removing cultural protections altogether.

Third, there is the fear that protecting culture by way of protections instituted by the government results in a regime of paternalism over what type of culture ends up being produced. Here, the worry is that culture (such as a screenwriter's script or a political journalist's article) will develop in a false manner that reflects where the Canadian government chooses to place funding rather than what the average Canadian is actually concerned with or interested in. However, while this might be a risk in some contexts, where the protection of cultural industries is concerned, the government does not have a hand in the actual content produced. Rather, the Canadian government is most interested in ensuring that Canadian content is even being created in the first place.

The final argument and possibly the most persuasive thus far, is that Canadian culture does not require special protection to begin with. As Dean and Dehejia suggest, "what seems

83 Robert Eberschlag, “Culture Clash: Canadian Periodical Policies and the World Trade Organization” (1998) 26 Man. L.J. 65 at 66. 
clear is that Canadian culture by its broadest definition is thriving, and fears about its fragility appear to be unfounded, or at any rate overblown." 84 Additionally, whether or not protections might have been required in the past, the argument is that the U.S. and Canada have been experiencing a divergence in values of late such that the two cultures are becoming so distinct from one another that protection would be redundant. ${ }^{85}$ This argument seems grounded in the idea of encouraging an open marketplace, and heavily related to the first argument noted above that unfairly restricting free trade should be avoided. Whether the foregoing is true or not does not really matter because there is still the perception among Canadians that Canadian cultural industries need protection, especially given the spirit of free trade between Canada and the U.S. In the end, it is really not for the U.S. to decide whether Canadian cultural industries should be protected — as long as Canadians believe protection is necessary, that ought to be enough.

\section{ARguments for Change in DeALing With TRADE AND CULTURAL INDUSTRIES}

Canada maintains a somewhat unique position with regard to the U.S. and it is exactly this predicament that informs the cultural industries issue between the two countries. One author notes that "it needs to be stressed that the relationship is highly asymmetrical. Canadians have likened their situation to 'sleeping with an elephant' ... Canada is necessarily aware of the United States while Americans are too often ignorant of their neighbor to the north." Change is required in the international regime of dealing with cultural industries for a number of reasons, mostly because what is currently in place is simply not working, especially in the context of the U.S. and Canada. Following are the four primary arguments for embarking on such change.

The first argument has to do with the lack of natural barriers between Canada and the U.S. in terms of language and geography, and the increased susceptibility of Canada to American cultural influence as a result: “Unlike Asians or Europeans, we don't have the luxury of being able to observe the American media system from a safe and comfortable distance." 7 Unfortunately, there is no mediating language between the U.S. and English-speaking Canada to offer somewhat of a barrier from the all-too-easy flow of information across the border. ${ }^{88}$ Additionally, there is the similar geography to consider and the fact that 80 percent of the Canadian population lives within 100 miles of the U.S. border. ${ }^{89}$ As the Massey Report noted, "Canada has a small and scattered population in a vast area; this population is

$84 \quad$ Supra note 36 at 318.

$85 \quad$ Ibid. at 319, 323. The authors go on to state at 323:

Socially, Canada has been much more progressive on matters such as gay marriage, abortion, and capital punishment, and moreso since the evident neo-conservative turn in American policy [especially post-9/11], at least of the current administration. Some argue that this divergence is supported in part by the continued fissuring of immigrant pools to the two countries: While the United States draws primarily from Spanish-speaking southern nations, Canada's immigration is made up heavily of English-speaking Asian immigrants.

$86 \quad$ Mulcahy, supra note 11 at 183.

$87 \quad$ Taras, supra note 73 at 193.

$88 \quad$ Matheny, supra note 1 at 253. It should be noted here that Quebec enjoys a better position to some extent since it has the advantage of the French language to stunt to a large degree the barrage of television, movies, and publications from the U.S. (and even English-speaking Canada). 
clustered along the rim of another country many times more populous and of far greater economic strength." ${ }^{90}$ Coupled with sharing the same language, this "leads to peculiarly close and intimate relations," 91 and Canada has little choice but to attempt to protect its cultural industries from the cultural hegemony of the U.S. ${ }^{92}$

Two concepts are tied together within the second argument: fears of "Americanization" and the need to maintain a "Canadian" perspective and identity in the face of that fear reveal the necessity of change for cultural industries on the international front. Clearly, this particular issue requires deep contemplation on both sides of the border about the meaning of culture in the context of the world today. However, it is difficult to see how this can happen given the huge disconnect in the way the U.S. and Canada view the concept of culture. One author even went so far as to condescendingly state that "it is not apparent that Canadians are well-equipped to discuss this issue."93 But this idea goes both ways and it is not until the international arena for cultural industries is changed that the two countries might find themselves in a better place to attempt to bridge the gap.

The third major argument for change with respect to trade and cultural industries has to do with issues of economies of scale and the huge advantage possessed by the U.S. where this is concerned. The U.S. is able to export its cultural products "at almost zero marginal cost," 94 because it has the opportunity to recoup its costs within its own domestic market before the product even reaches a foreign market. ${ }^{95}$ This is most definitely not the case for Canada, which has a population approximately one-tenth the size of that of the U.S., and where buying an American product is often far cheaper than producing a Canadian version. ${ }^{96}$ In addition, while cultural products from the U.S. enjoy a high degree of popularity in Canada, this is not true for Canadian cultural products in the U.S. that flaunt their "Canadianness," as they rarely elicit any reaction beyond general indifference. ${ }^{97}$

Finally, there is the not insubstantial issue of the incompatibility of the current international trade regime with the concept of protecting and promoting cultural industries, a major concern for many countries. As one commentator notes, "cultural industries have unique characteristics that require a unique approach."98 The World Trade Organization and the NAFTA are ill-equipped to handle the highly contextual nature of cultural goods and services within the confines of the current trade regime, especially since little to no allowance is made by the WTO for cultural considerations. Where trade is concerned, there has been an international push for the imposition of environmental and human rights

$90 \quad$ Supra note 20 at 11 .

91 Ibid.

92 According to a UNESCO report, "more than one-third of the USA's exports of core cultural goods went to Canada”: see UNESCO Institute of Statistics (UIS), International Flows of Selected Cultural Goods and Services, 1994-2003(2005), online: UIS <http://www.uis.unesco.org/template/pdf/cscl/IntlFlows_ en.pdf $>$.

93 Graham Carr, “Culture” in Duncan Cameron \& Mel Watkins, eds., Canada Under Free Trade (Toronto: James Lorimer \& Company, 1993) 203 at 212.

Dean \& Dehejia, supra note 36 at 316.

See also Thompson, supra note 16 at 399.

Taras, supra note 73 at 195 .

Goff, supra note 13 at 541.

Eberschlag, supra note 83 at 94. 
concerns regarding the way in which trade is conducted internationally; this ought also to be so for cultural industries, particularly to the extent of protecting and promoting national identities and cultural diversity. ${ }^{99}$

Based on the foregoing arguments for and against change in international dealings of cultural industries, there seem to be two available options. Either the international trade regime can carry on in blissful ignorance (only to see an increasing number of cultural trade clashes in the future), or it can be altered to reflect the current state of globalization as well as to acknowledge the very real concern of many nations regarding their potentially threatened cultural identities.

\section{FINDING A NEW WAY: Promoting Culture and Encouraging Trade}

As this article has demonstrated, trade in culture is markedly dissimilar from the trade of regular products and services. This inherent uniqueness infuses the discussion of trade and cultural industries with a sense of urgency because the current regime in place is simply not equipped to handle the burgeoning issue. At this point in time, it is highly unrealistic to think that the GATT will be altered to include a general exemption for, or even a consideration of, cultural industries. Neither is the NAFTA a realistic forum since it has only regional influence and, as discovered in the Periodicals case, given the right circumstances, it can be bypassed entirely in favour of the WTO rules dispute settlement regime.

The creation of an international agreement dealing specifically and only with cultural industries would seem to be the most logical way to approach the issue of the interaction between culture and trade. Placing such an agreement within the purview of the WTO is likely to be the most effective means of achieving this objective given its dispute settlement mechanism and its role as the umbrella organization of the GATT, the GATS, and the TRIPS Agreement. As SAGIT has suggested, “a new strategy that would involve negotiating a new international instrument that would specifically address cultural diversity, and acknowledge the legitimate role of domestic cultural policies in ensuring cultural diversity”" ${ }^{100}$ would go a long way in making sure cultural industries are somewhat shielded from the ill effects of international trade.

The WTO is the most appropriate forum for a general agreement on trade in culture because the GATT and GATS are already triggered where the international sale of goods and services occurs among member nations. It only makes sense that since cultural products overlap with the jurisdiction of the GATT and GATS, the framework within which those agreements exist should be used for its efficiency (relative to a cultural agreement existing outside the scope of the WTO) and so jurisdictions remain clear. That the same dispute settlement mechanism would apply to the GATT, the GATS, the TRIPS Agreement, and the proposed cultural agreement would add a degree of predictability to the trade in culture; member nations would be presumably more informed in the course of their dealings. Additionally, despite its shortcomings, the WTO framework is appealing because it has a 
more global scope than any regional agreement or mere declaration could hope to have, not to mention that the framework is currently in place and the wheel would not have to be reinvented.

The actual scope of an international agreement dealing with cultural industries would perhaps be the most contentious issue because the idea of whether protection is needed is already fairly contentious and subjective in the first place. How will it be decided how much protection is necessary and how will it be determined when protection is no longer necessary? Looking at the experience of the U.S. and Canada, the U.S. is unlikely to benefit from any extra protection that a cultural agreement might have, whereas for Canada, such an agreement might be viewed as necessary for protecting its cultural industries. Therefore, it may be prudent to include a sliding scale of protection that depends on a number of factors and considerations so that a nation's cultural "industries that have developed sufficient competitiveness would not be protected." ${ }^{101}$ This approach may result in a situation where some cultural industries within a nation might enjoy protection, while others might not (depending on economic circumstances). The goal of the agreement, at the end of the day, is to ensure that nations, in the course of trade, are actively engaging in a discussion that includes cultural considerations and that nations acknowledge "that not all trading partners are equal, and neither [are] all products and services,” particularly in the context of trade in culture and cultural industries. ${ }^{102}$ From a trade standpoint, such an agreement would promote a standard closer to the concept of fair trade whereby an atmosphere of "equality of competitive opportunity” would be encouraged and maintained. ${ }^{103}$

The first step in eventually bringing an international agreement on trade in culture to fruition involves promoting the acceptance of culture within the trade framework. Canada is not the only country facing the erosion of its cultural identity; however it is perhaps in the best position to do something about the issue given its extensive experience in dealing with its cultural industries, and given the fact that this experience was obtained within such close proximity to the extreme cultural hegemony of the U.S. ${ }^{104}$ It has been said that "Canada currently plays a leading role in fostering initiatives to exempt culture from international trading regimes, treat culture as more than a commodity, and find multilateral instruments to value cultural diversity and expression within national and international frameworks.”105 One way in which Canada has sought to promote the concept of culture and trade is by founding the INCP, which was discussed earlier in Part III. Canada relies on the INCP to essentially lobby for the acceptance of the idea of cultural diversity in the context of trade at the international level. ${ }^{106}$ By promoting the acceptance of culture as having a valid place within and beside the trade debate, future negotiations for an actual general agreement on trade in culture will hopefully proceed more smoothly with less acrimony and controversy. ${ }^{107}$

$101 \quad$ Devlin, supra note 74 at 188.

102 UNESCO 25 Questions, supra note 7 at Answer 5.

103 Chi Carmody, "When 'Cultural Identity Was Not at Issue’: Thinking About Canada-Certain Measures Concerning Periodicals” (1999) 30 Law \& Policy Int’l Bus. 231 at 238. 


\section{Conclusion}

Historically, Canada has generally adopted a primarily defensive stance with regard to cultural industries, however the country has been shifting in the past few years to a more offensive and proactive position whereby the encouragement and promotion of culture and cultural industries is the name of the game not just at the national level but at the international level as well. Canada has been concerned with its cultural industries since the early 20th century and has undertaken a number of methods and strategies for protecting and promoting its film, television, music, and publishing industries from the hegemonic encroachment of the U.S. These methods have included, inter alia, government subsidies, restriction on foreign investment and ownership, and the establishment of Canadian content quotas. Canada has also established government initiatives charged with the task of protecting and promoting the interests of its cultural industries, for instance, Trade Team Canada - Cultural Goods and Services.

When it comes to the international arena of cultural industries, the NAFTA and the GATT have played the largest role where the U.S. and Canada are concerned. Unfortunately, both agreements have been found to be greatly lacking in dealing with cultural industries. The NAFTA, although it includes a cultural industries exemption, has a corresponding clause that allows retaliation when the exemption is utilized. The GATT, on the other hand, fails to even contemplate the idea of culture (beyond a small exemption for film) and, as such, lacks the contextual flexibility to deal effectively with goods infused with cultural characteristics. Both of these agreements played out in the saga surrounding the Periodicals case of the mid1990s, and it was here that the GATT's shortcomings with respect to cultural industries were truly realized. Nevertheless, a major step forward was taken when the UNESCO Convention on the Protection and Promotion of the Diversity of Cultural Expressions came into force on 18 March 2007.

While a number of challenges face the protection and promotion of cultural industries, it is becoming increasingly important as the world becomes increasingly globalized that some form of action needs to be taken to bring trade and the concept of culture within the same purview. The best way, at this point, is likely to be the creation of a general agreement on trade in culture that fits within the regime of the WTO. Support for such an agreement will largely depend on how a nation conceives of the interaction of trade and culture - the more a country views culture as a mere commodity, the less likely that country is to acknowledge the nuances of cultural expression as an aspect of national and cultural identity. Ultimately, as global citizens it is our responsibility to ensure that cultural diversity in the world is appreciated and promoted to the greatest possible extent in the face of the economic interests of dominant cultures. 